\title{
In vitro propagation of Ananas comosus L. Merr. (Morris)
}

\author{
H. Elias 1,a, R.M. Taha ${ }^{2}$, H. Sani1 ${ }^{1}$, N.F. Khamarul Huda11, B.A. Ahmed ${ }^{2}$, S. Abdullah ${ }^{3}$ and \\ S.A. Zakeri ${ }^{1}$ \\ ${ }^{1}$ Faculty of Resource Science \& Technology, Universiti Malaysia Sarawak, 94300 Kota Samarahan, Sarawak, \\ Malaysia; ${ }^{2}$ Department of Biochemistry and Biotechnology, Centre for Research and Development (CRD), PRIST \\ Deemed University, Vallam, Thanjavur 613 403, Tamil Nadu, India; ${ }^{3}$ Faculty of Science, University of Malaya, \\ 50603 Kuala Lumpur, Malaysia.
}

\begin{abstract}
Ananas comosus L. Merr. (Morris) commonly known as pineapple, is an economically important fruit in Malaysia. Among the pineapple producers in the world, Malaysia has put massive efforts to fulfill the high domestic and global market demand. Several attempts have been made recently by integrating biotechnology in conventional breeding concerning issues on the shortage production of pineapple fruits. The fruit productivity could be enhanced via a tissue culture system as it might provide the good quality of planting materials in industrial scale throughout the years. Hence, this study was designed to assess the effectiveness of utilizing tissue culture technique to produce sufficient plantlets of pineapple. The procedure involved culturing aseptic axillary buds excised from suckers in treatments with various concentrations of 6-benzylamino purine (BAP) to induce shoot multiplication. The suckers were successfully disinfected by soaking in $100 \%$ Clorox for 3 min with $80 \%$ survival and free contamination. The best result for this experiment was obtained in MS supplemented with $3.0 \mathrm{mg} \mathrm{L}^{-1} \mathrm{BAP}$, produced the highest no. of shoots per explant with the highest no. of leaves per explant. Besides, it was found that the treatments added with more than $3.0 \mathrm{mg} \mathrm{L}^{-1}$ BAP decreased the number of shoots and leaves per explant. Nevertheless, further advance study especially in quality control should be done to verify the quality of fruits meet the standard for commercialization.
\end{abstract}

Keywords: axillary bud, BAP, micropropagation, pineapple, regeneration, root, shoot

\section{INTRODUCTION}

Ananas comosus L. Merrill or commonly known as pineapple, is an herbaceous perennial plant that belongs to family Bromeliaceae. It originated from South America and abundantly cultivated in tropical and subtropical areas, specifically over a wide range of latitudes from $30^{\circ} \mathrm{N}$ in the northern hemisphere to $33^{\circ} 58^{\prime} \mathrm{S}$ in the south (Malézieux et al., 2003). There are approximately 2794 species of the plant that have been classified in 56 genera and typically categorized into five groups namely Cayenne, Queen, Spanish, Abacaxi and Maipure. They are mostly epiphytic and many strikingly ornamental that grow up to 1-2 $\mathrm{m}$ tall and length with characteristics such as a stocky, distinct central cylindrical, erect and club-shaped stem surrounded by about $30 \mathrm{~cm}$ length of tough, waxy and dense compact rosette leaves, inscribed with the general shape of a spinning top and crown presents as leafy parts on the top of fruits (d'Eeckenbrugge et al., 2003). The crown, sucker, slip, hapa, butt and stump are parts of the plant mainly used in vegetative reproduction.

A. comosus is considered as one of the most demanded exotic fruits in the world as it represents the third most important tropical fruits after bananas and mangoes (Chen et al., 2019; Nath et al., 2019). In Malaysia, the fruits become the fourth largest (6.3\%) usage in agrofood after durian (41.3\%), banana (18.0\%), and rambutan (9.8\%), and among the varieties cultivated include Morris, Josapine, Yankee, Gandul, N36, and MD2 (Abd Halim,

aE-mail: ehashimah@unimas.my 